\title{
THE LIVERPOOL MEDICAL SCHOOL AND ITS PHYSICIANS (1642-1934)
}

\author{
by
}

\section{LORD COHEN OF BIRKENHEAD}

THE medical history of Liverpool recapitulates in broad outline the medical history of any large provincial city in this country. Of the earliest Liverpool doctors, little more than the names are known. As early as $\mathbf{1 5 6 0}$ there is in the Town Books a reference to one Dormishe or Darbie Ulster-'phisicion', who lived in Higher Bebington in Cheshire. But it is not until the seventeenth century that fuller medical records exist.

The first well-known doctor was Silvester Richmond, born in Garstang in 1616, the year in which Harvey announced in his Lumleian Lectures his proof of the 'perpetual motion of blood in a circle'. We know nothing of his training but Richmond practised in Liverpool from 1642 to 1672 as 'Professor of Physick and Chirurgery'. He was held in high regard by his fellows and played an important rôle in civic affairs, being elected Mayor in 1672 the year in which he retired to Thornton Hall, Crosby, a few miles north of Liverpool, on the road to what is now Southport, where he died in 1692. The monumental brass formerly over his burial place in St. Nicholas's Parish Church recorded his 'Thirty years indefatigable care and practice in this town and country'. His clock, after an eventful history, finds its resting place in the entrance hall of this Institution.

There are records of less than twenty doctors who practised in this city before the end of the seventeenth century. These included Alexander Norres who was Mayor in 1694 (Liverpool has had five medical mayors and two Lord Mayors); and Henry Ambrose who was licensed to practise medicine in 1662 by the Bishop of Chesterin the diocese of Chester, which then included Liverpool. It was not until 1880 that the see and bishopric of Liverpool was created. There are also records of barbersurgeons.

By the opening of the eighteenth century, when Liverpool was thriving as a port, it attracted a number of doctors most of whom had received their training at Edinburgh; some at Glasgow; and a few at Oxford, Cambridge, Leyden or Louvain. In the first quarter of the eighteenth century the most fashionable physician was Samuel Angier of Union Street, who attended the great Blundell family of Crosby, and it is from the Blundell Diary that we learn something of contemporary medical practice and of three women practitioners-the widow Bolton described as a Chirurganess, and of two others-a Mrs. Bolson and a Mrs. Maginis.

By 1745 , the population of Liverpool had grown to 18,000 . There had for a decade been moves to establish in Liverpool, as in other large towns, a voluntary hospital for the poor, and in 1748 was completed the first Infirmary, sited on Shaw's Brow, where St. George's Hall now stands. The history of this and the later two infirmaries, and the other teaching hospitals built in the nineteenth century, is the subject of a later communication by Dr. John Ross.

When the Infirmary opened in 1749 , three physicians and three surgeons were 


\section{The Liverpool Medical School and its Physicians (1642-1934)}

appointed. Training of future doctors was carried out from the first. Each surgeon was allowed to bring his apprentices to assist him with operations, and he could also bring two paying pupils to be instructed in surgery. For example, in 1758, at the age of fourteen, Henry Park was apprenticed to his uncle, James Bromfield, one of the first surgeons appointed to the Infirmary in 1749. Henry Park, who advocated conservative surgery for carious joints in place of the then customary practice of amputation, and his close friend and Infirmary colleague, Edward Alanson, who introduced 'flap' amputation, placed Liverpool in the fore-front of eighteenth-century English surgery.

Apprenticeship and pupillage continue at the Infirmary, not only under surgeons, but also under the many distinguished physicians attached to the Infirmary staff in the second half of the eighteenth, and first quarter of the nineteenth century, before systematic teaching began. I should add that at that time, and indeed until the first decade of this century, all physicians and surgeons were also in general practice. Only a few of these eighteenth-century physicians need be mentioned.

The earliest and most outstanding physician was Matthew Dobson, F.R.S., physician to the Infirmary from 1770 to 1780 , who was the first to prove in 1776 that the sweet taste of diabetic urine is due to sugar. When Charles Best visited Liverpool in 1957 he told me that of all the major characters in the story of diabetus mellitus, the only portrait missing from his personal archives is that of Matthew Dobson. Dobson's portrait certainly hung in the Infirmary until 1874 when it was, Bickerton records, 'unfortunately damaged by a mischievous house-surgeon with a peashooter'.

One of Dobson's contemporaries on the staff of the Infirmary was Thomas Houlston, appointed in 1774, at the age of twenty-nine. His special interests included resuscitation by artificial respiration after drowning. This he performed successfully in many cases brought into the receiving house, opened on the north side of the old dock. He is recalled also for his attempt to establish Liverpool as a fashionable spa on the basis of a chalybeate spring in St. James's Quarry, the site of our great Anglican Cathedral. In 1773, Houlston published an essay extolling its fine qualities, 'its taste cool and refreshing at first, but later turning austere and inky; it imparted warmth to the stomach, and produced an inebriating sensation'. Houlston claimed that it was beneficial in almost all diseases and excellent for those who 'fell away' without cause. A Liverpool surgeon, James Worthington, had, by only a few months, anticipated Houlston's essay, in a pamphlet entitled Experiments on the Spa at Mount Sion, near Liverpool. However, their combined efforts to attract patients to the spa failed, and within twenty years the spring became almost inaccessible from bushy overgrowth, and never again were claims made for the healing properties of Liverpool springs.

In 1780, Joseph Brandreth, who had earlier succeeded to Dobson's practice, was appointed physician to the Infirmary. He was born in Ormskirk, graduated M.D. Edinburgh in 1770, with a thesis on intermittent fevers. He was one of the first doctors in this country to realize the value of cold water sponging in fever. Like Richmond and Norres, a century earlier, he played an active part in the affairs of the community, and in 1802 was presented with the freedom of the borough.

The most distinguished Liverpool physician in the last quarter of the eighteenth century was James Currie, a graduate of Glasgow, an F.R.S. and F.R.C.P.Ed., who was appointed to the Infirmary in 1786. He had arrived in Liverpool in 1780, and a 


\section{Lord Cohen of Birkenhead}

year later, when smallpox broke out in the town, he wrote advocating general inoculation. He extended Brandreth's observations on the application of cold water, preferably sea water, to the febrile patient, and by the then available thermometry sought, with some success, to specify its indications and contraindications. In Garrison and Morton's Medical Bibliography, Currie's paper, entitled 'Medical reports, on the effects of water, cold and warm, as a remedy in fever and febrile diseases', is included, though the appended note which states that 'Currie was the first in Gt. Britain to use cold water packs in the treatment of fever' overlooks the work of his colleague, Brandreth.

Currie was the prime mover in establishing in Liverpool in 1792 the lunatic aslyum to be attended by the physicians and surgeons attached to the Infirmary (on its site was later built the Faculty of Arts of the University of Liverpool), and in March 1796 he initiated a scheme for erecting a Fever Hospital, or House of Recovery, in Liverpool. This latter met with much opposition so that Currie had died by the time it was ready for use in 1806. His death in August 1805 was due to tuberculosis at the early age of forty-nine. But Currie deserves our gratitude not only for his contributions to medicine, but for his fearless humanitarianism. First, there was his courageous advocacy of negro emancipation at a time when the slave traffic was the major source of wealth of the then merchant princes of this city (including the father of W. E. Gladstone, who lived in Rodney Street, where W. E. was born, delivered by Henry Park).

Secondly, was the arrival in Liverpool in 1800 of many French prisoners, victims of Napoleon's wars, who were confined to the Borough Gaol, where so many died that Currie was asked to investigate. He had no doubt that starvation was the cause, and in association with friends he offered to supply food and clothing, but this was refused. He thereupon wrote to the P.R.S., Sir Joseph Banks, who showed the letter to Pitt. An investigation upheld his conclusion, though he was censured for his interference, incurred the opprobrium of the town's merchants, and branded as a Jacobin. To the non-medical world Currie is best known as the biographer of Robert Burns.

The most original of the Liverpool physicians in the first half of the nineteenth century was James Carson, M.D., F.R.S. Originally a Minister of the Church of Scotland he later graduated M.D. Edinburgh in 1799. His thesis was De viribus quibus sanguis circumvehitur. He was the first to suggest that the circulation of the blood is maintained not only by vis a tergo-the heart's systole, but also by vis a fronte, due to the elasticity of the lung and atmospheric pressure producing negative intrapleural and intraauricular pressure during ventricular systole resulting in a pressure gradient in the veins towards the heart. He developed this view by careful experiment and clinical observation and applied it in treatment (e.g. in artificial pneumothorax, which he first persuaded Mr. Bickerstaff, a surgical colleague to carry out in a patient with advanced consumption in 1822-nearly three-quarters of a century before Garrison's attribution of the operation to Carlo Forlanini in 1895). I have discussed fully Carson's work in an earlier Gideon de Laune Lecture, published in Medical History, 1963, 7, 1-12, and in my recent Harveian Oration to the Royal College of Physicians, so I shall refrain from its further elaboration, except to reiterate that I have no doubt that Carson is amongst the most brilliant and original of medical scientists of the period. 


\section{The Liverpool Medical School and its Physicians (1642-1934)}

A contemporary of Carson's was Thomas Stewart Traill, who graduated in Edinburgh in 1801, and two years later settled in Liverpool. Traill was a pioneer in forensic medicine, and attained such eminence in this field that he was appointed in 1832 to the Chair of Forensic Medicine in Edinburgh. He was one of the most learned of classical scholars and edited the eighth edition of the Encyclopaedia Britannica. Of fine physique, he swam across the Mersey in his youth. When in 1821, he appeared at a fancy dress ball in 'the classic garb and helmet of Epaminondas' the local press thought it a pity 'that the modern Greeks had not now such a leader to shake off the Turkish yoke'. He and his family were present at the opening of the LiverpoolManchester Railway in 1830. At the celebration dinner which followed the opening, Traill's wife and daughters were toasted as amongst the first ladies to travel on a railway in England. Traill, replying to the toast on their behalf, ventured to prophesy that, "from the experiments I have this day witnessed, I expect to live to see the day when a man may breakfast in Liverpool and dine in London on the same day'. This expectation of Traill's was fulfilled before his death in 1862. Today, the journey, since electrification of the track, can take as little as two hours thirty-five minutes.

I should here interpolate, as chronologically apposite, that from 1789 to 1807 , when the slave trade became illegal-due in no small part to the writings and efforts of a great Liverpool citizen and M.P., William Roscoe-the staff of the Infirmary acted as examiners under the Act of 1789 , which was designed to ameliorate the lot of slaves shipped from the African coast. This Act stipulated that with rare exceptions no ship or vessel shall leave a port in this country unless at least one surgeon shall accompany it, and that such a surgeon shall produce 'a certificate or warrant of his having passed a specified examination at Surgeon's Hall, or amongst other places, some public or county hospital, or at the Royal College of Physicians or Royal College of Surgeons at Edinburgh, or shall have served as a surgeon or surgeon's mate in H.M. fleet or armies. .. '. Liverpool, being then the chief English port engaged in the slave trade, established a licensing board at the Infirmary, and in the eighteen years it was in being 634 candidates were examined, of whom 532 passed.

The next physician who merits mention is Richard Formby, for to him, and to William Gill, a surgeon on the Northern Hospital, must be attributed the beginnings of formal medical teaching in Liverpool. Both established schools of anatomy based on the London schools, e.g. of William Hunter in Great Windmill Street. Richard Formby was born in Liverpool, a member of a distinguished Lancastrian family who owned a large estate at Formby, a few miles north-west of Liverpool; the present head of the family is the distinguished E. N. T surgeon-Brigadier Miles Formby. Richard Formby graduated from Caius College, Cambridge, in 1813, and took his M.D. in 1818. He practised in Liverpool and was appointed physician to the Infirmary in 1832. He delivered the Harveian Oration of the Royal College of Physicians in 1852.

The entry to medicine at that time was still by apprenticeship to a member of the Infirmary staff or to a physician or surgeon in private practice. Apprentices supplemented this experience by formal lectures at schools of anatomy and in Liverpool, as I earlier noted, two such schools existed-directed respectively by Richard Formby and William Gill. The average number of students in each of these schools was about forty, and included not only medical students but also artists. Lectures were given on 


\section{Lord Cohen of Birkenhead}

midwifery, medical jurisprudence, and diseases of children as well as on anatomy, and these lectures were recognised by the College of Surgeons and Society of Apothecaries for their diplomas. Sir William Mitchell Banks, one of Liverpool's most distinguished surgeons, and then lecturer, and later Professor of Anatomy, in his address at the opening of the 1872 session of the medical school, described in detail the state of medical education in Liverpool before 1834. There were the customary difficulties in obtaining bodies for dissection which led to Burke and Hare-like activities in Liverpool resulting in criminal trials of the body-snatchers. The passing of the Anatomy Act in 1832 after the Select Committee inquiry of 1828 was to remedy this.

Despite the anatomy schools of Formby and Gill, there was increasing clamour for the establishment in Liverpool of a single Medical School. In 1828, a Liverpool paper, The Kaleidoscope, deplored the scant facilities for medical education in Liverpool and strongly urged support for a medical school so that: "the erroneous and popular opinion "that there is a great want of clever medical men in Liverpool". .. so universal in London, and current everywhere, will then be satisfactorily refuted: we shall then cease to be inundated with such shoals of Welshmen, Irishmen, and, last and worst of all-Scotchmen'.

After much discussion the Liverpool Royal Institution School of Medicine was opened in 1834; lectures there were given in anatomy by Formby and Gill; Formby lectured also in medicine, and lecturers were appointed in botany, chemistry, materia medica, medical jurisprudence, midwifery and surgery: clinical instruction was carried out at the Infirmary. Ten years later, in 1844, the School was transferred to Dover Street, behind the second Infirmary in Brownlow Street, and was henceforth known as the Liverpool Infirmary School of Medicine. The Infirmary Committee declined to furnish the Medical School so each lecturer contributed $£ 5$ for the purpose, and although the Infirmary Committee in 1846 agreed to maintain the fabric of the School, the lecturers undertook to be responsible for cleaning, for keeping the windows in repair, and for paying the porters' wages. The role of the other hospitals, especially the Northern, Southern, and Stanley in medical teaching is the theme of Dr. John Ross's contribution.

In 1847, the Infirmary in its annual report, commenting on the advantages of its Medical School to medical students observed: 'They will prosecute their studies under the care of their parents or masters without being exposed to danger from too early freedom from restraint amidst the temptations of the Metropolis, receiving at the same time all the benefit which a large and well conducted hospital can afford'.

The number of students was never high, and practically all were local; in 1865 there were, for example, twenty-eight. But some were to gain national fame. Of these the best known is Sir Dyce Duckworth, Bart., who studied at the Royal Infirmary Medical School (the title Royal had been conferred on the Hospital on the occasion of Queen Victoria's visit to Liverpool in 1850) though he qualified in Edinburgh in 1862, returning however to Liverpool to work on his M.D. thesis. After a year in the Naval Medical Service he left for London, and his later and distinguished career is bound up with St. Bartholomew's and the Royal College of Physicians, London, in which he held high office, including for thirty-nine years, the Treasurership. 


\section{The Liverpool Medical School and its Physicians (1642-1934)}

As in other major provincial cities, the School of Medicine was to play a decisive rôle in the evolution of university education in Liverpool. A Liverpool Association for the Promotion of Higher Education was formed, and with the Council of the School of Medicine held a joint meeting in November 1877 to prepare a draft scheme for the establishment of a University College. In May 1878, a public meeting at the Town Hall, called by the then Mayor, Arthur Bower Forwood (a great grandfather of a former Minister of Health, Dennis Vosper, later Lord Runcorn) supported the project and a subscription list was opened. The response exceeded the target, and several chairs were endowed. The occupants included Sir Oliver Lodge as Professor of Experimental Physics, and William (later Sir William) Herdman as Professor of Zoology and Botany.

The College opened in the former lunatic asylum, in January 1882, adjacent to the Royal Infirmary, and though the Medical School was not to merge with it until two years later, four of its lecturers were appointed to serve on the Senate-T. H. Waters as Professor of Medicine, Rushton Parker as Professor of Surgery, Mitchell Banks as Professor of Anatomy, and Richard Caton as Professor of Physiology. These, and indeed a few subsequent appointments to the chairs, were ad vitam, which occasionally resulted in difficult and embarrassing situations, e.g. Rushton Parker held on to his chair for well beyond his capacity to lecture so that it was necessary to ensure proper standards of surgery lectures by appointing a Professor of Regional Surgery in 1913 -William Thelwall Thomas-and forcibly preventing Parker from trespassing on these.

In order that a Liverpool student before 1884 should obtain a medical degree he had to seek it as an external student of the University of London. In 1880, however, the Victoria University had been established at Manchester and its charter allowed colleges other than Manchester's Owens College to be admitted as constituent members of Victoria University provided they satisfied the prescribed conditions. The Victoria University was at first empowered to grant degrees in any subject other than medicine and surgery, but when, in March 1883, this restriction was removed the University College and the Liverpool School of Medicine decided to join in seeking admission to the Victoria University. This was granted in November 1884 and saw the demise of the Royal Infirmary School of Medicine. Liverpool medical students now became eligible to sit for degrees of Victoria University until the University of Liverpool secured its own Charter in 1903 with the 16th Earl of Derby as its first Chancellor. By this time the University was housed in the present Victoria building. Other contributors will deal with developments in other medical disciplines-surgery, preventive medicine, tropical medicine, physiology, biochemistry, anaesthesia, etc., but it is proper that I should add a few words about those who have occupied the chair of medicine since 1882, when University College was founded, until 1934 when I was myself elected to the chair.

From 1882 to 1884 the chair was occupied by Thomas Houghton Waters. I should interpolate that the sole duty of the professor until 1934 was to give a course of systematic lectures to senior students. Waters came to the Royal Infirmary as senior house surgeon in 1853, having studied in London (St. George's); in 1855 he was appointed lecturer in anatomy, physiology and pathology, at the Royal Infirmary School 


\section{Lord Cohen of Birkenhead}

of Medicine, and in 1860 Honorary Physician to the Northern Hospital having gained in the previous year the Fothergillian gold medal of the Medical Society of London for an outstanding essay on the anatomy of the human lung. This work led him to take a special interest in chest diseases on which he wrote a standard work which achieved a wide circulation both in the United Kingdom and the U.S.A. In 1871, he was elected to the Royal Infirmary. He held the chair of medicine for two years only but he continued as physician to the Royal Infirmary till 1886 when he reached the age limit, though his private practice continued for some years. He took an interest in civic affairs and became an Alderman of the borough. A keen advocate of higher education he laboured hard for the establishment of a college or university in Liverpool, and was chairman of one of the early committees established for this purpose. He was President of the British Medical Association when it held its Annual Meeting in Liverpool for the third time in 1883. He died in his eighty-seventh year in 1912, the year the British Medical Association held its Annual Meeting for the fourth time in Liverpool under the presidency of Sir James Barr of whom more anon.

Water's nephew was Thomas Robert Bradshaw, Dublin born, and a graduate of Trinity College; he came to Liverpool for house appointments and was later appointed physician to the Royal Infirmary. He is best known for his writings on myelopathic albumosuria; his test for albumose in urine was formerly widely used. He married a daughter of Thomas Robinson Glynn, a physician appointed to the Royal Infirmary in 1871 at the age of thirty, who held the chair of medicine for thirty-eight years from 1884 until he retired in 1922, the year in which I qualified.

Glynn was born in 1841, the son of a Liverpool shipowner. He studied medicine at St. Bartholomew's Hospital and in Paris, graduated M.B. London in 1865, and M.D. in 1879. His association with Liverpool was life long. After serving on the honorary staff of the Children's and Northern Hospitals he was elected to the Royal Infirmary in 1871, and he, too, was one of the small energetic group which played a prominent rôle in founding University College. He was undoubtedly the best all-round clinician of his generation in Liverpool; a dynamic and inspiring teacher who based his lectures on the correlation of physical signs and pathological findings; he was an outstanding clinical observer whose Bradshaw Lecture on 'Hysteria' (1913), and Lumleian Lecture on 'Infective Endocarditis' at the Royal College of Physicians(1903) have not only the literary qualities of an Allbutt or Osler, but the Lumleian Lectures had the additional merit of being illustrated by his own watercolour drawings of the lesions in infective endocarditis found at autopsy. In the old pathology museum of the university where his son, Ernest, was Professor of Pathology from 1912 to 1928, there were his excellent watercolour paintings of pathological specimens, and also of clinical conditions. He was indeed an artist of considerable merit, with a fine appreciation of colour, and exhibited many attractive landscapes at local exhibitions. He had a great love of music; he was an organist and delighted in singing even when in his eighties.

I well recall his lectures which I attended in my final year. He would arrive about 8 a.m. for a 9 a.m. lecture and chalk extensive notes of the lecture, which filled a blackboard which was at least twenty feet wide and four feet high. On the desk in front of him were gathered classical texts from which he would read relevant excerpts and show plates. I recall especially Charcot's Nouvelle Iconographie photographique 


\section{The Liverpool Medical School and its Physicians (1642-1934)}

de la Salpêtrière which he used to illustrate diseases of the nervous system. I doubt if he ever projected a lantern slide. Although then in his eighty-second year with the slight stoop of age, he had a most distinguished appearance and a remarkable command of English and French. I rate him amongst the best half-dozen lecturers I have heard.

It is well to remind ourselves that when Glynn retired from the chair of medicine in 1922 clinical pathology was in its infancy and radiology as a diagnostic instrument for the detection of lesions of the soft tissues, e.g. lungs and alimentary tract, was still very imprecise. Glynn who had retired from the Royal Infirmary in 1901 made scant reference to these methods of diagnosis; he had, of course, had little experience of them.

Nor did Glynn's successor, John Hill Abram, born at Waterloo, part of Liverpool, in which he spent practically the whole of his professional life, except for a year at University College, London, where he graduated M.B. with first-class honours. He was appointed to the staff of the Royal Infirmary in 1902. In 1907, he was elected Professor of Therapeutics in the University in succession to William Carter; and from 1922 until he reached retiring age in 1924, for by then ad vitam appointments had ceased, he was Professor of Medicine.

For him Glynn was an oracle whose word was beyond dispute, and in consequence his teaching, much appreciated by students, was dogmatic and incisive. He was a first-class clinician of the old school, who preferred his clinical diagnosis even if an X-ray or pathological report did not support it. Like Glynn he was meticulous in his clinical examination of a patient and his interpretation of his findings in terms of morbid anatomy. I was his house physician and later registrar during his two years' tenure of the chair and am ever grateful for his many kindnesses. Occasionally students who were slack or unobservant felt the lash of his tongue; indeed when he retired the students presented him not only with a watercolour painting to add to his own choice collection to show their gratitude and affection, but also a formidable birch rod, which was described as 'the insignia of the Order of the Birch, presented for conspicuous merit in the application of the art over an extensive period'. Their true feelings and appreciation of his many kindly acts for the student body were shown by the fact that, though a bachelor, many generations of students always referred to him as 'Pa Abram'.

Before I proceed to touch upon the next occupant of the chair of medicine, I must mention briefly two other physicians on the staff of the Royal Infirmary during the Glynn era who merit inclusion in this record for their contributions to the Liverpool school.

The first is Richard Caton whose pioneer contributions to electro-encephalography commenced as early as 1875. Caton was an Edinburgh graduate in 1867. A year later he settled in Liverpool, and became physician to the Royal Infirmary, and lecturer in physiology in the Royal Infirmary School of Medicine. He was a prime mover in the creation of University College, and was from 1882 to 1891 the first holder of the chair of physiology. At that time, the custom in most medical schools was that the chairs of anatomy and physiology were part-time and held respectively by a senior surgeon and a senior physician. Caton was the first to recognize that this arrangement was inimical to the development of the basic medical sciences. As early as 1873 he wrote that 


\section{Lord Cohen of Birkenhead}

'The science is at a disadvantage, depending too much on the efforts of isolated men who can only spare to it a small part of their time. The gain to science, and the ultimate benefit to the country would probably be great if one or more Government supported laboratories were established, and some of the more eminent physiologists paid to devote their entire time to the work'.

By 1891, he had persuaded George Holt, a member of the well-known family of shipowners, to endow a full-time chair of physiology. The first incumbent was Francis Gotch, who left four years later to become the first Waynflete Professor of Physiology at Oxford. His successor was C. S. S. Sherrington, who held the chair for eighteen years during which his most seminal contributions to the physiology of the nervous system were made. The full-time chair of Anatomy was established three years later, endowed by the Chancellor, the 16th Earl of Derby, and held by A. M. Paterson.

Caton's interest in the university never waned, and he reached the high office of pro-chancellor. He became a city councillor and devoted much time to the promotion of public health, and in 1907, to the gratification of the whole medical profession in Liverpool, was elected Lord Mayor.

He was a classicist and historian. He travelled extensively in the Middle East and published papers on 'The Temples and Ritual of Asklepios, Hippocrates and Cos', and his Harveian Oration of the Royal College of Physicians in 1904 was on 'Imhotep -the Medicine and Medicine God of the Egyptians'. He was indeed a selfless and indefatigable worker in many fields, and of few could it be more worthily written'Nullum quod tetegit non ornavit'.

An entirely different character was Sir James Barr, an Ulsterman who graduated at Glasgow in 1873, and took his M.D. in 1882. After a period as house physician at the Northern Hospital he entered general practice and shortly afterwards succeeded Dr. Mitchell Banks (later Sir William) as medical officer to Kirkdale Prison. He was later ordered by the Secretary of State for Ireland (Arthur Balfour) to report on the conditions in Irish prisons. He brought on himself a storm of wrath and threats to his life when he reported that Nationalist prisoners were being treated with great leniency, considering their refusal to obey prison rules. Historical situations recur! His knighthood in 1905 was widely regarded as a reward for these services. He was President of the British Medical Association when it met in Liverpool in 1912, shortly after the introduction of the National Insurance Act, to which he was bitterly hostile. One of his milder references to it was 'the most gigantic fraud that had been perpetuated on a confiding public since the days of the South Sea Bubble'. In his earlier days he was a much sought after physician. He held views, not widely accepted, on the physics of respiration, and he believed in the treatment of the typhoid patient by immersion in tepid water. But as he grew older he became an uncritical enthusiast for many unorthodox and irrational methods of treatment. He fell under the spell of Abram and his box and adopted spondylotherapy and similar cults with uncritical ardour. In controversy his weapon was the bludgeon not the rapier. In Munk's Roll of Fellows of the Royal College of Physicians his character is aptly summarized as a 'vigorous pugnacious man, with a strong Ulster accent, impervious to criticism and incapable of moderation'.

Dr. Robert J. M. Buchanan was appointed to the Royal Infirmary in 1901 after a 


\section{The Liverpool Medical School and its Physicians (1642-1934)}

distinguished student career, graduating in Victoria University with honours in 1888, and winning the gold medal for his M.D. thesis a year later. His special interest, on which he wrote a widely-used textbook, was forensic medicine and toxicology. $\mathrm{He}$ held this chair from 1909 until he retired in 1924. In clinical medicine he was a sound, experienced and reliable consultant. His expert microscopy and draughtsmanship is reflected in his manual-The Blood in Health and Disease. He regularly exhibited paintings and watercolour sketches, especially of North Wales, at local exhibitions. He had his foibles. He convinced himself that he could delineate the outlines of the kidneys and pancreas by percussion of a patient's back; and he was apt to elaborate at great length how as an apprentice joiner he helped to build the third Royal Infirmary in which he was later to become the senior physician. But he was a lovable man, of singular versatility and abounding energy, a more than competent artist, a lover of music, and a raconteur of the first order.

John Hay, my immediate predecessor in the chair of medicine, held the chair from 1924 to 1934, and was well known to many of you. He qualified in 1895, and after other hospital appointments was elected assistant physician to the Royal Infirmary in 1907. He retained his youthful appearance, lively personality, and irrepressible gaiety until shortly before his fatal illness in 1959. Unlike many of his colleagues, he grasped the opportunities which newer methods of investigation offered, especially in cardiology. He became a disciple of James Mackenzie, visiting him in Burnley on Sunday mornings, and founded in the Royal Infirmary one of the first and best of provincial heart centres. But he was a general physician of distinction as well as a cardiologist. His notable contributions to the literature of heart disease brought him wide recognition as reflected in his many honours. He was an accomplished artist. His watercolours and Christmas cards drawn by hand adorn the walls of many of his friends, and much prized by the victims were the caricatures he drew of his colleagues on agenda papers or menu cards during many a boring meeting or post-prandial speech. He played the violin and gardened, especially after he retired, as he did all else, with unbridled enthusiasm and verve.

My own appointment to the chair of medicine in 1934 is a fitting end to this chapter of the Liverpool School and its physicians.

But before concluding, since there is no reference in the programme to obstetrics, I should add a few words about two remarkable professors of obstetrics and gynaecology. Towards the latter part of the nineteenth century, the hospital accommodation for women was shocking; the old Hospital for Women was a block of converted houses in Shaw Street, and a small Lying-in Hospital served until a Maternity Hospital was opened in 1885 contiguous to the Victoria building. Many Liverpool students had to travel to the Rotunda Hospital, Dublin, to gain experience in midwifery. In November 1898, Henry Briggs, an Edinburgh graduate, and Lister gold medallist, was elected professor and immediately the position was transformed. At his own expense he furnished a hostel, Brownlow House, installed caretakers and an obstetric assistant, and very soon students from all over the United Kingdom were coming to Liverpool for their obstetric training. When I was resident there in $1921 \mathrm{my}$ fellow students were two from Edinburgh, two from St. Andrews, and two from Newcastle. During his tenure of the chair, from which he retired in 1921, he built at his own 


\section{Lord Cohen of Birkenhead}

expense a museum in his department, which was situated in the old Infirmary Medical School.

He was a remarkably original teacher, often interpolating apparently irrelevant stories, which however one soon realized fixed an important point in one's memory. He would bring one student out of the class and use him as a stooge or whipping boy. I trust you will not think that vanity inspires this story.

Like Glynn, Briggs wrote notes of his lectures on the board, and in the first lecture of our term he spoke on the history of midwifery and there, on the board, were the names of Ambroise Paré, Chamberlen, Semmelweis, Lister and others. After discoursing for thirty minutes, he stopped suddenly, and pointing a finger at me (I was sitting in the front row) said: 'You, sir, come out here, sir'. I went. He then thrust a specimen in my hands and asked, 'What is that, sir?' I replied, 'A uterus, sir'. 'Very good, sir', he said, patting me on the back. 'Can you tell me anything about it?' 'It's very large', said I. 'Very, very good, sir', said the Professor and with an even stronger slap on the back asked, 'Why is it very large?' 'Because it's a pregnant uterus, sir'. With this he asked 'What is your name, sir?' I told him. Then, striding to the board he declared, 'I shall write it above that of Ambroise Paré', and he did.

Briggs' successor in the chair was William Blair-Bell, born in Wallasey, the son of a doctor, and trained at King's College, London. He will be remembered as a gynaecologist of international repute with a deeply scientific approach to his specialty. In 1909, he formulated a 'working hypothesis' of cancer, namely, that the chorionic epithelium, particularly the syncytium, is a normally malignant tissue, and that if a means could be found to check its growth, the same agent might arrest malignant growths. He tried, with this objective, various preparations but finally chose lead-an abortifacient. His first case was remarkably successful, but although the problem was pursued for years and he had to face such cynical observations as that he had achieved the alchemist's dream of turning lead into gold (for large fees were charged to cover the costs of the research), there is no doubt of his untiring zeal and devotion to the advance of medical science, for which he was always prepared to make personal sacrifices. His permanent memorial is the Royal College of Obstetricians and Gynaecologists of which he was the prime mover, architect and first president. Liverpool has since provided two presidents of the College, Sir Arthur Gemmell, and the present President, Sir Norman Jeffcoate.

A pessimistic critic wrote of Liverpool at the end of the eighteenth century: 'Art and science are inimical to the spot; absorbed in the nautical vortex, the only pursuit of the inhabitants is commerce. Liverpool is the only town in England of any preeminence, that has not one single erection or endowment for the advancement of science, the cultivation of the arts, or promotion of useful knowledge. It may be truly said with the son of Sirach, that wisdom cries out in the streets and no man regards it'.

This conference can touch on only a tithe of Liverpool's medical achievements since those words were written over a century and a half ago, but I trust that the range and splendour of those achievements will serve not only to obliterate the stain of the eighteenth-century critic, but will also pardon the pride that I and thousands of others must feel when we recall that we are alumni of a medical school to which mankind owes so great a debt. 